assessing the available evidence, chiefly figures, reports, and speeches from the Castro regime and its officials, the author concludes that despite the handicap of untrained cane cutters the amount of cane harvested during 1970 was nearly sufficient to attain the goal, and that the effort proved futile because of transportation and milling delays, milling inefficiency, and improper cutting. Noting that the harvest was nonetheless the largest in Cuban history and that the goal might have been attainable, Roca emphasizes that any analysis of the effort must take what he calls the concurrent opportunity costs, i.e., the impact of the effort in other economic sectors, into consideration and that it is these factors which render the effort ill-advised. For the priority placed on the sugar goal resulted in the allocation of virtually all effort to it, and the involvement of nearly half the nation's labor force in the harvest at some point or other. The result was a disaster in the rest of the economy that would have offset the ten million ton harvest even if it had been achieved. Availability of consumer goods and production in all sectors dropped drastically, while non-sugar agricultural production actually declined from 1968-1970 because of the extension of sugar planting. The author concludes that ten million tons was a political target rather than an economic one, and that efforts to attain it were impeded by subjective factors, i.e., non-economic considerations such as decisions based on ideology and the ineffectiveness of the program of moral incentives. He notes that the failure forced the abandonment of moral incentives, and a reorientation of Castro's policy toward economic considerations with an emphasis on production.

K.J.G.

Robert Conrad has culled his note-cards gathered during his more than fifteen years of research and produced a useful bibiographical guide. Brazilian Slavery: An Annotated Research Bibliography (Boston: G.K. Hall \& Co., 1977. Pp. xvi, 163. Author index. $\$ 15.00$ ) includes primary and secondary materials published on the subject of the slave trade and its suppression, slavery and abolition. The section devoted to bibliographical and research aids is particularly strong on guides to Portuguese and Brazilian legislation relating to slavery. Conrad's incisive remarks about the usefulness of each entry is invaluable.

C.A.P.

\title{
Obrtuary Notice
}

France Vinton Scholes, Research Professor Emeritus at the University of New Mexico, died in Albuquerque on February 11, 1979, after a career that spanned six decades as a professional historian, teacher, archive scholar and University administrator. Scholes was educated at Harvard under Professors Roger B. Merriman, Charles H. McIlwain, Frederick Jackson Turner and Clarence Haring. He taught at Radcliffe College, The Massachusetts Institute of Technology and Colorado College before joining the faculty of the University of New Mexico in 1924 where he served as professor, department chairman, graduate 
dean, and academic Vice President until 1956 when he was appointed research professor.

Between 1931 and 1946, Professor Scholes was Head of the Post-Columbian History Section, Division of Historical Research of The Carnegie Institution of Washington, D. C. There he was part of the superlative interdisciplinary team of researchers-anthropologists, historians, ethno-historians-who mounted a pan scientific attack on Mayan and Southwestern history. Scholes will be particularly remembered as an indefatigable researcher in Spanish and Mexican archives, a scholar who had a flair for the discovery of important, often unique, manuscripts which triggered major revisionist studies. He will also be remembered as a generous man with his knowledge, and a teacher with uncompromising scholarly standards. He published over fifty major contributions to the history of the New Mexico colony in the seventeenth century; the Maya area of Yucatan, Cozumel and Guatemala; and of central Mexico where he became the foremost expert on the life and times of Fernando Cortes.

Dr. Scholes was a Senior Editor of The Americas and a charter member of The Academy. In 1956 he was honored with The Serra Award of The Americas. The January 1971 issue of The Americas was dedicated to him with essays written by his former students.

Tulane University

Richard E. Greenleaf

New Orleans, Louisiana 